\title{
In vitro comparison of the erosive potential of four different wines on human dental enamel
}

\begin{abstract}
SUMMARY
Background/Aim: This study aimed to investigate the erosive potential of wines derived from Anatolia on human teeth in vitro. Material and Methods: In this study two red (Öküzgözü, Boğazkere) and two white (Sultaniye, Narince) wines, citric acid and distilled water were used to investigate erosive effects. The $\mathrm{pH}$, titratable acidity, iron and calcium ion levels of the groups were measured. Each group included 10 specimen and they were exposed to $25 \mathrm{ml}$ of wine sample for 5 seconds, artificial saliva for 10 seconds for 10 times. The initial and the final phosphate concentrations were measured by the UV spectrophotometer and the difference between the measurements was calculated. One sample was examined under a scanning electron microscope and the data were analyzed statistically using One-way ANOVA and Pearson correlation test. Results: Mineral loss and erosive lesion depth values were ranged from highest to the lowest Sultaniye, Boğazkere, Öküzgözü and Narince, respectively. Correlation between mineral loss and $\mathrm{pH}$ was statistically significant $(p<0.01)$. However, there was no correlation between the iron and calcium ion level and mineral loss. Conclusions: All the investigated wines have $p H$ values below the critical value for enamel dissolution while Sultaniye was significantly more erosive than the others. There is a negative correlation between $\mathrm{pH}$ and erosive potential of the wine. Within the limits of this in vitro study, it can be expected that a regular consumption of wines might cause dental erosion.
\end{abstract}

Key words: Erosion, Dental Erosion, Titratable Acidity, Wine

\author{
Dilara Şeyma Alpkılıç ${ }^{1}$, Şule Batu ${ }^{2}$ \\ ${ }^{1}$ Department of Prosthodontics, Faculty of \\ Dentistry, Istanbul University, Istanbul, Turkey \\ ${ }^{2}$ Department of Basic Medical Sciences, Faculty \\ of Dentistry, Istanbul University, Istanbul, \\ Turkey
}

\section{ORIGINAL PAPER (OP)}

Balk J Dent Med, 2022;41-46

\section{Introduction}

"Dental erosion" or "erosio dentium", which is a clinical term used in dentistry, can be defined as the chronic, pathological and localized removal of dental hard tissues without bacterial activity ${ }^{1-3}$. In recent years, there has been an increasing interest for dental erosion. There is a growing concern within the dental profession over the problem, and it is important for the clinicians to recognize the early symptoms of dental erosion ${ }^{3}$.

While erosion takes place in the mouth environment, the amount of mineral removed from the hard tissues of the tooth depends on a number of factors; such as the $\mathrm{pH}$ of the acid, the buffering capacity, the concentration of the acid and the contact time of the acid ${ }^{4,5}$. In addition, it has been stated that the calcium, phosphate and flouride ions, which are contained in the beverages in sufficient quantity, have an anti-erosion effect ${ }^{6-8}$.

Despite the existence of a traditional mindset that $\mathrm{pH}$ is the main factor in determining the erosive potential of beverages, it has been recently accepted that the amount of titratable acidity is the determining factor ${ }^{4}$. The initial $\mathrm{pH}$ value only tells us the concentration of hydrogen ions present in the drink. However, as the titratable acidity value increases, the time it takes for saliva to neutralize this acidity will increase ${ }^{4}$.

Epidemiological studies and numerous case reports have proven that diet plays a crucial role in the development and progression of dental erosion. It is stated 
that long-term and frequent intake of fruit juices results in formation of dental erosion (8-10). Wines are also in the category of acidic beverages as they are made of grapes. While the initial $\mathrm{pH}$ of the grape juice is 3.0 , the $\mathrm{pH}$ of the wines is measured between 3.3 and $4^{11}$.

The Anatolian territory is one of the world's oldest wine regions. It is known that Turks produced and consumed wine besides the traditional beverages. There are about 600-1200 grape varieties in Anatolian region and many different wines can be produced by processing these grapes. Despite this, about 60 different types of wine are produced today ${ }^{12}$.

The aim of this study is to compare the erosive effects of wines on enamel surface and investigate the correlations between $\mathrm{pH}$, titratable acidity, iron and calcium irons amongst the groups. The null hypothesis is there is no difference between the erosive effects of different wines on human enamel.

\section{Material and Methods}

\section{Specimen Preparation}

This in vitro study has been reviewed and approved by the Ethical Committee of Istanbul University, Faculty of Dentistry (2020/26). Nineteen unerupted wisdom teeth were collected to evaluate the erosion potential.

Collected unerupted wisdom teeth were disinfected and the debris on the surface was removed. They were kept in a $0.9 \%$ sodium chloride solution to prevent drying out $^{11}$. The crown parts of the teeth were separated from the roots at cemento-enamel junction under water cooling with a separator. Then each crown was cut into four smaller pieces under water cooling by using diamond burs. A round shaped sticker with a diameter of $3 \mathrm{~mm}$ (A: $7.065 \mathrm{~mm}^{2}$ ) was placed on each sample to create an exposure window. After placing the sticker, the surface of the specimen was covered with acid-resistant nail polish. Then the sticker was taken out. Prior to creating erosive lesions, all samples were kept in a solution containing 1 $\mathrm{mM}$ CaHPO4 $+1 \mathrm{mM} F$ for $24 \mathrm{~h}$ for standardization, then rinsed with distilled water and allowed to dry.

\section{Study Groups}

Two red and two white wines, from various winemaking regions in Anatolia were selected as study groups. The $\mathrm{pH}$ and titratable acidities were measured and shown in Table 1. The initial $\mathrm{pH}$ of the wines was measured with a $\mathrm{pH}$ meter (Orion, model 420A, Thermo Fischer Science Inc., Waltham, MA, USA) at room temperature. The titratable acidities of the wines were determined by sequential addition of $0.1 \mathrm{M} \mathrm{NaOH}$ to $5 \mathrm{ml}$ wine sample until the $\mathrm{pH}$ reached 7 . The initial phosphate concentrations of the wines were determined spectrophotometrically using a colorimetric assay based on the molybdenum reaction at a wavelength of $650 \mathrm{~nm}$ (UV- 1601 PC, Shimadzu Corp., Kyoto, Japan) ${ }^{13}$. In addition, calcium and iron concentrations in the wines were determined using ion selective electrodes in a commercial laboratory (Kalite Group Laboratories).

Table 1. Wines used in this study and their chemical properties

\begin{tabular}{|c|c|c|c|c|c|c|c|}
\hline Grape & $\mathrm{pH}$ & Titratable acidity $(\mu \mathrm{M})$ & Alcohol (\%) & Manufacturer & Type & Region & Abbreviation \\
\hline Boğazkere & 3.47 & 640 & $\% 12$ & Buzbağ & Red & Diyarbakır & BK \\
\hline Öküzgözü & 3.76 & 570 & $\% 12$ & Buzbağ & Red & Elazığ & OG \\
\hline Narince & 3.79 & 610 & $\% 13$ & Kavaklidere Ancyra & White & Tokat & NA \\
\hline Sultaniye & 3.2 & 844 & $\% 12.5$ & Kavaklıdere & White & Denizli & SU \\
\hline
\end{tabular}

\section{Erosion Protocol}

The erosion protocol is shown in Figure 1. Tooth samples were randomly divided into 6 groups $(\mathrm{n}=10)$ with 10 samples in each group (4 experimental groups +1 positive control group +1 negative control group). In order to simulate the intake of one glass of wine, samples in each group were subjected to $25 \mathrm{ml}$ of wine for $5 \mathrm{sec}$, then kept in the same amount of artificial saliva for $10 \mathrm{sec}$ and washed with distilled water. This procedure was repeated 10 times for each sample individually (Figure 1). The difference between the initial and final measurements was calculated and the values were adjusted to surface area of this exposed enamel window size of $7.065 \mathrm{~mm}^{2}$. Lesion depths of tooth windows were calculated by the formula below:

Depth of erosive lesion $=($ Mineral loss in the tooth $) /$ (Hydroxyapatite density x Test area) ${ }^{13}$

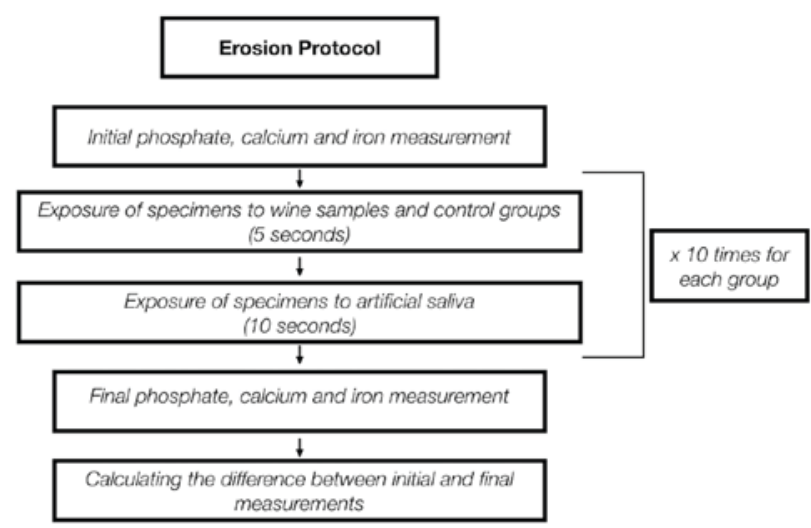

Figure 1. Erosion protocol and the study design 


\section{Scanning electron microscope imaging}

For scanning electron microscope (SEM) imaging, one of the teeth was cut sagittally. Same disinfection and standardization protocol were applied to that specimen. Two exposure windows were created. One of the windows was opened and the specimen was exposed to Sultaniye. The same erosion protocol was applied as explained before. After the erosion simulation, the other window was opened and used as control.

Prior to scanning electron microscope examination, the surface of the specimen was coated with a thin gold foil. The specimen was examined under a scanning electron microscope (Quanta 450 FEG, FEI Technologies Inc., Oregon, United States) under x1000 and x5000 magnification.

\section{Statistical analysis}

Statistical analyzes were done using SPSS program (version 12; SPSS Inc, Chicago, Ill, USA). The mean values and standard deviations of the chemical properties of wines were calculated. The relationship between chemical properties and mineral loss between groups was investigated using One - Way ANOVA (Post-Hoc Tukey's HSD test) with the significance level of 0.001 . The relationship between mineral loss, lesion depths and chemical properties was examined using Pearson correlation test $(\alpha=0.01)$.

\section{Results}

Mean and standard deviation values for phosphate measurements and erosive lesion depth measurements are shown in Table 2. Mineral loss and erosive lesion depth values were ranged from highest to the lowest Sultaniye, Boğazkere, Öküzgözü and Narince, respectively. OneWay ANOVA tests showed a significant difference between the groups in terms of mineral loss $(p<0.001)$.

Table 2. Mineral loss and depth of erosive lesions on enamel surface after immersion of the specimen in study and control groups

\begin{tabular}{lccccc}
\hline Group & Content & Mineral loss $(\mu \mathrm{g})($ Mean \pm SD) & Erosive Depth $(\mu \mathrm{m})($ Mean \pm SD $)$ & $\mathrm{pH}$ & Titratable acidity $(\mu \mathrm{M})$ \\
\hline $\begin{array}{l}\text { Positive control } \\
(\mathrm{n}=10)\end{array}$ & Citric acid & $0.3936 \pm 0.0087^{\mathrm{a}}$ & $0.019 \pm 0.0001^{\mathrm{f}}$ & 2.5 & 300 \\
$\begin{array}{l}\text { Negative control } \\
(\mathrm{n}=10)\end{array}$ & Distilled water & $0^{\mathrm{e}}$ & $0^{\mathrm{k}}$ & 7 & 0 \\
BK $(\mathrm{n}=10)$ & Boğazkere & $0.032 \pm 0.0004^{\mathrm{c}}$ & $0.0015 \pm 0.00005^{\mathrm{h}}$ & 3.47 & 640 \\
OG $(\mathrm{n}=10)$ & Öküzgözü & $0.027 \pm 0.0037^{\mathrm{c}}$ & $0.0013 \pm 0.00016^{\mathrm{h}}$ & 3.76 & 570 \\
NA $(\mathrm{n}=10)$ & Narince & $0.015 \pm 0.0033^{\mathrm{d}}$ & $0.0007 \pm 0.00017^{\mathrm{j}}$ & 3.79 & 610 \\
SU $(\mathrm{n}=10)$ & Sultaniye & $0.075 \pm 0.0040^{\mathrm{b}}$ & $0.0036 \pm 0.00019^{\mathrm{g}}$ & 3.2 & 844 \\
\hline
\end{tabular}

*Difference on the letters shows the difference between groups and same letters indicate no statistical differences according to the statistical analyses.

In terms of mineral loss and erosive lesion depth, a statistically significant difference was found between the positive and negative control groups and the experimental groups $(p<0.001)$. Values obtained in terms of mineral loss and erosive lesion depth are ranged from highest to the lowest Sultaniye, Boğazkere, Öküzgözü and Narince, respectively. When the enamel loss and erosive loss values were examined, no statistically significant difference was found between the Öküzgözü and Boğazkere groups, while the difference between the other groups was statistically significant $(p<0.001)$.

While there was a negative correlation between low $\mathrm{pH}$ and mineral loss $(\mathrm{p}<0.01)$, no significant relationship was found between calcium and iron ion concentrations and mineral loss $(p>0.01)$. SEM images of Sultaniye group confirm the erosive effects. As a result, typical honeycomb appearance and irregular structure caused by dental erosion were seen in the experimental group images (Figures 2 and 3).

Table 3. Correlation between PH values and Mineral Loss

\begin{tabular}{llcc}
\hline & & $\mathrm{pH}$ & Mineral Loss \\
\hline $\mathrm{pH}$ & Pearson Correlation & 1 & $-0.935^{*}$ \\
& Significance (2-tailed) &. & .000 \\
Mineral Loss & Pearson Correlation & 1 & $-0.935^{*}$ \\
& Significance (2-tailed) &. & .000 \\
\hline
\end{tabular}

*Correlation is significant at 0.01 level (2-tailed). 


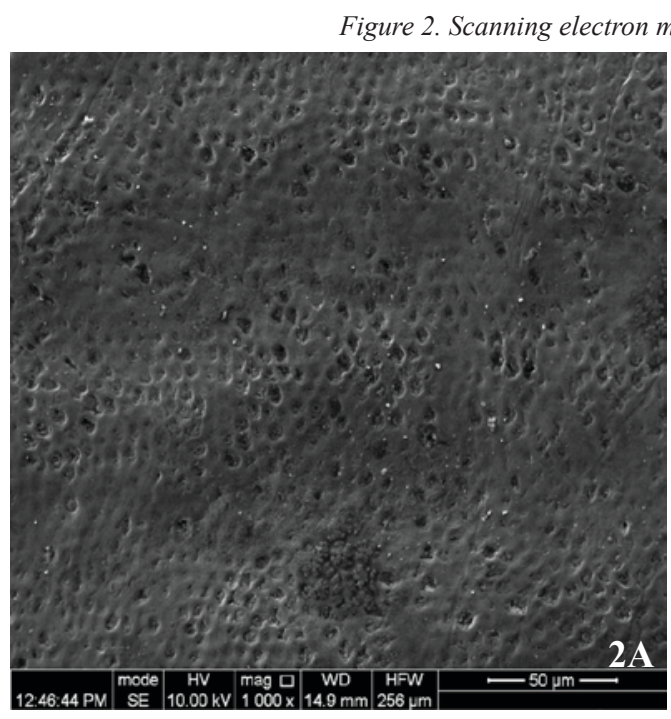

Figure 2A-Non-erode tooth surface of tooth hard tissues with regular and smooth structure under SEM with 1000 magnification

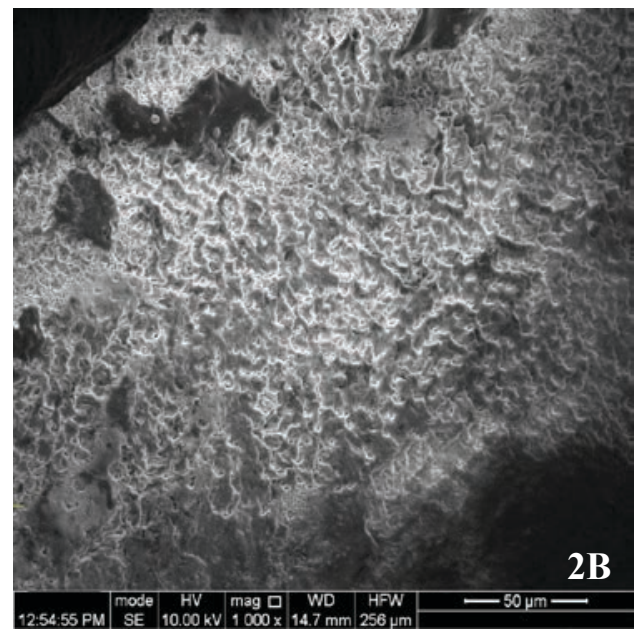

Figure 2B. Eroded tooth surface of tooth hard tissues with irregular structure under SEM with 1000 magnification

Figure 3. Scanning electron microscope images under x5000 magnification.

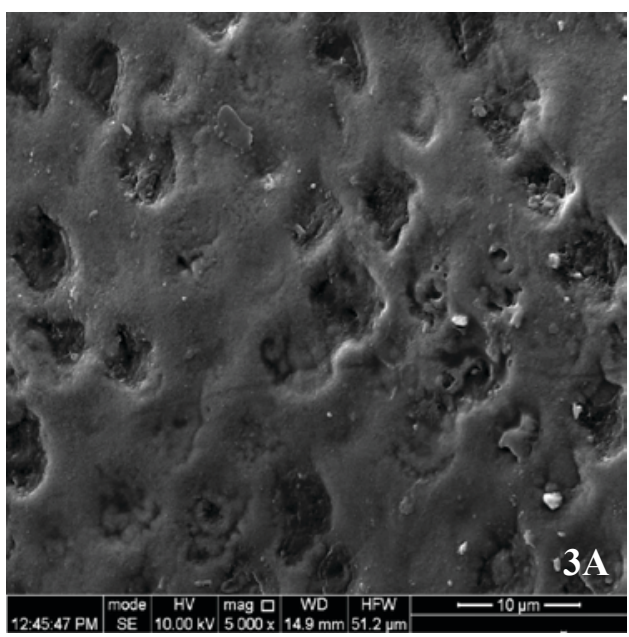

Figure 3A. Non-erode tooth surface of tooth hard tissues with regular and smooth structure under SEM with $\times 5000$ magnification

\section{Discussion}

Dental erosion has become more common as there has been an increase in the consumption of acidic beverages with a variety of acids that have been implicated with dental erosion. Early symptoms of dental erosion are absent or very limited. Clinicians must carry out a diagnostic protocol for early stages of erosive lesions. When enamel demineralization is detected at a more advanced stage, the damage becomes irreversible.

Several studies $3,11,14,15$ and case reports ${ }^{16,17}$ have shown that, the erosive potential of wine is dependent on its chemical properties. However, there is no study in the literature about the erosive effects and chemical properties of the wines from the grapes grown in the Anatolian

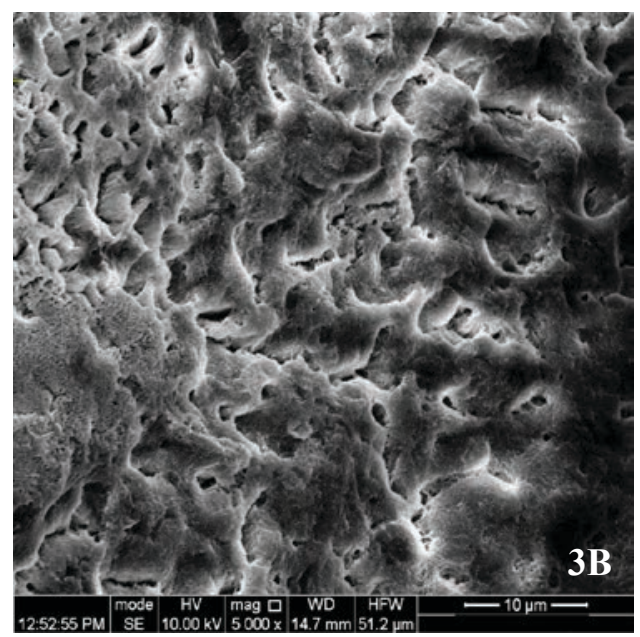

Figure 3B. Eroded tooth surface of tooth hard tissues with irregular structure under SEM with $x 5000$ magnification

region. The results of the current study show that, wines derived from the Anatolian region have a different erosive potential against enamel depended on their chemical properties and the null hypothesis was rejected.

During food intake under normal conditions, food and beverages act on the teeth for a very short time due to the washing effect of saliva. Some previous studies have reported, either the substrates were exposed to acidic beverages for a very long time $e^{11,14,18}$ or the role of saliva was neglected during the experiments ${ }^{11,14}$. The current study was designed to enable the erosion that occurs during an intake of a glass of wine $(250 \mathrm{ml})$ to be examined under conditions where the washing effect of saliva was also simulated. 
Our findings are consistent with the study results of Ehlen et al..$^{19}$, who found a relationship between the mineral loss in dental hard tissues and both $\mathrm{pH}$ and TA. However, our results contradict with other studies claiming that the erosion potential is directly and primarily affected by $\mathrm{pH}^{8,10,20}$. This difference can be explained by the different experimental conditions and study designs.

Willershousen et al..$^{21}$ investigated the erosive effects of four red and four white wines with different $\mathrm{pH}$ levels. They concluded that, the white wines were more erosive than the red wines. Our results contradict with the results of their study. In the mentioned study, white wines have lower $\mathrm{pH}$ level than the red wines that results in more erosion. It is a common fact that, white wines have lower $\mathrm{pH}$ and acidity than red wines. However, in our study one of our white wines has higher $\mathrm{pH}$ and TA than the red wines, resulting with less erosive potential.

Mok et al. ${ }^{15}$ simulated intermittent $24 \mathrm{~h}$ enamel exposure to wines and concluded that white wines caused erosive lesions with $68 \mu \mathrm{m}$ depth. These data were similar to the results of this study as the deepest erosive lesions were seen in Sultaniye group that has the lowest $\mathrm{pH}$. However, the mean depth of the erosive lesions of Sultaniye group is $36 \mu \mathrm{m}$. The difference between the two studies should be explained by the specimen exposure time.

In our study, no significant relationship was found between the amount of iron contained in wines and mineral loss ( $p>0.05)$. Bueno et al. ${ }^{7}$ concluded that ironcontaining gels inhibit the solubility of tooth enamel in the presence of erosion risk. In addition, Kato et al. ${ }^{6}$ stated in their in vitro study that the solubility of enamel powder against acidic drinks decreased in the presence of iron.

According to the results of this study, $\mathrm{pH}$ has a negative correlation with erosive potential however the concentration of the acid in the beverage and whether it is strong or not, the alcohol level and the concentration of other ions may all create one specific content for beverages and may affect the erosive potential of beverages.

In the current study, Sultaniye showed the lowest $\mathrm{pH}$ and highest titratable acidity values that resulted in the highest mineral loss from tooth surface and deepest erosive depth on enamel. Therefore, Sultaniye was chosen as a representative of severe dental erosion for SEM imaging. The SEM images confirmed that and deep lesions with irregular surface images were captured on enamel under magnification.

However, there are some limitations of this study. As it is not ethical to conduct this study in vivo, this study was designed in vitro with its own limitations. Despite the effort to simulate the washing effect of saliva by using artificial saliva, the protective effect of pellicle was not possible to simulate. Only limited number of wines were used and more studies with more and different brands and grapes of wines should be conducted.

\section{Conclusions}

Under the limitations of this study, it can be stated that alcoholic beverages, are one of the risk factors for dental erosion. Wines derived from the Anatolian region have low $\mathrm{pH}$ and cause erosion on the enamel surface even during a short contact, such as consuming a glass of wine. Level of $\mathrm{pH}$ has a negative correlation with erosive potential and there is no correlation between the erosion and iron and calcium ion level. Within the limits of this in vitro study, it can be expected that a regular consumption of wines might cause dental erosion.

Acknowledgements Authors have no commercial relation and any conflict of interest with any of the wine manufacturers or companies.

\section{References}

1. Kwek SXR, Mian M, Hall C, Xie Z, Yong R, Kaidonis J. Nanoscratch testing for the assessment of enamel demineralization under conditions simulating wine erosion. Aust Dent J, 2015;60:12-17.

2. Wiegand A, Attin T. Occupational dental erosion from exposure to acids - a review. Occup Med, 2007;57:169176.

3. Brand HS, Tjoe Fat GM, Veerman ECI. The effects of saliva on the erosive potential of three different wines. Aust Dent J, 2009;54:228-232.

4. Chan AS, Tran TTK, Hsu YH, Liu SYS, Kroon J. A systematic review of dietary acids and habits on dental erosion in adolescents. Int J Paediatr Dent, 2020;30:713-733.

5. Santhiya B, Puranik MP, Sr U. Risk factors, assessment and management of dental erosion in dental setting- A literature review. Int J Appl Dent Sci, 2019;5:28-36.

6. Kato MT, Sales-Peres SH de C, Buzalaf MAR. Effect of iron on acid demineralisation of bovine enamel blocks by a soft drink. Arch Oral Biol, 2007;52:1109-1111.

7. Bueno MG, Marsicano JA, Sales-Peres SHC. Preventive effect of iron gel with or without fluoride on bovine enamel erosion in vitro. Aust Dent J, 2010;55:177-180.

8. Lussi A, Megert B, Shellis RP, Wang X. Analysis of the erosive effect of different dietary substances and medications. Br J Nutr, 2012;107:252-262.

9. Hemingway CA, Parker DM, Addy M, Barbour ME. Erosion of enamel by non-carbonated soft drinks with and without toothbrushing abrasion. Br Dent J. 2006;201:44750.

10. von Fraunhofer JA, Rogers MM. Dissolution of dental enamel in soft drinks. Gen Dent, 2004;52:308-312.

11. Willershausen B, Callaway A, Azrak B, Kloss C, SchulzDobrick B. Prolonged in vitro exposure to white wines enhances the erosive damage on human permanent teeth compared with red wines. Nutr Res, 2009;29:558-567.

12. Sen I, Tokatli F. Characterization and Classification of Turkish Wines Based on Elemental Composition. Am J Enol Vitic, 2014;6:134-142.

13. Chen PS, Toribara TY. Warner H. Microdetermination of Phosphorus. Anal Chem, 1956;28:1756-1758. 
14. Caneppele TMF, Jeronymo RDI, Di Nicoló R, de Araújo MAM, Soares LES. In Vitro assessment of dentin erosion after immersion in acidic beverages: surface profile analysis and energy-dispersive $\mathrm{X}$-ray fluorescence spectrometry study. Braz Dent J, 2012;23:373-378.

15. Mok TB, McIntyre J, Hunt D. Dental erosion: in vitro model of wine assessor's erosion. Aust Dent J, 2001;46:263-268.

16. Gray A, Ferguson MM, Wall JG. Wine tasting and dental erosion. Case report. Aust Dent J, 1998;43:32-34

17. George R, Chell A, Chen B, Undery R, Ahmed H. Dental Erosion and Dentinal Sensitivity amongst Professional Wine Tasters in South East Queensland, Australia. Sci World J, 2014; $16: 516975$

18. Santos EJL Dos, Meira IA, Sousa ET De, Amaechi BT, Sampaio FC, Oliveira AFB De. Erosive potential of soybased beverages on dental enamel. Acta Odontol Scand, 2019;77:340-346.

19. Ehlen LA, Marshall TA, Qian F, Wefel JS, Warren JJ. Acidic beverages increase the risk of in vitro tooth erosion. Nutr Res, 2008;28:299-303.
20. Ablal MA, Kaur JS, Cooper L, Jarad FD, Milosevic A, Higham SM, et al. The erosive potential of some alcopops using bovine enamel: an in vitro study. J Dent, 2009;37:835-839.

21. Willershausen B, Callaway A, Azrak B, Kloß C, Schulzdobrick B. Prolonged in vitro exposure to white wines enhances the erosive damage on human permanent teeth compared with red wines. Nutr Res, 2009;29:558-567.

Conflict of Interests: Nothing to declare.

Financial Disclosure Statement: Nothing to declare.

Human Rights Statement: None required.

Animal Rights Statement: None required.

Received on January 1, 2021

Revised on Jun 10, 2021.

Accepted on September 2, 2021.

Correspondence

Dilara Şeyma Alpkılı

Department of Prosthodontics

Faculty of Dentistry, Istanbul University, Istanbul, Turkey

e-mail: s.alpkilic@istanbul.edu.tr 